\title{
Mechanism Analysis of Coal Mine Entrepreneurial Social Capital
}

\author{
Ping Wang, Wei Shi \\ School of Management, Xi'an University of Science and Technology, Xi'an, China \\ Email: wplqym@163.com, swgirl_888@yahoo.com.cn
}

Received May 25, 2012; revised June 25, 2012; accepted July 2, 2012

\begin{abstract}
This paper first focuses on the concept of coal entrepreneurial social capital under the background of safety production; Then, analyzes the source of coal entrepreneurial social capital and their action mechanism in order to improve the performance of safety and economy; Finally, this article puts forward the possible application safety production fields and its prospect of entrepreneurial social capital in coal mine enterprise and safety in production.
\end{abstract}

Keywords: Entrepreneurial Social Capital; Coal Mine Enterprise; Action Mechanism; Safety Production

\section{Introduction}

Modern coal enterprise should depend on the formation and improvement of the social capital value to enhance coal mine enterprise value. For the coal enterprise in the transitional period of reform, entrepreneurial social capital is especially crucial to the development of enterprises. At present, scholars entrepreneurial social capital research most focus on concepts, characteristics, and some scholars focus on empirical research, such as high-tech, family enterprises and manufacturing enterprises. Currently, few scholars ever conduct systematic research and analysis of the application of entrepreneurial social capital theory in coal enterprises. In conclusion, studies on the coal mine entrepreneurial social capital are of practical and theoretical significance.

\section{Coal Mine Entrepreneurial Social Capital Concept and Connotation}

\subsection{The Concept of Entrepreneurial Social Capital}

The concept of social capital is put forward by a French scholar Bourdieu in 1970s, and he thought that social capital is a kind of system networks through possession and acquisition of actual or potential resource concentration [1]. Coleman in the United States of America of sociological community first explicitly use the concept of "social capital" and he points out that social capital is held by individuals with social structure resource for the characterization of capital property. Its formation depends on the relation between persons according to the beneficial action of manner change [2]. The earliest re- search on entrepreneurial social capital, which is conducted by scholar Potter from the structural perspective, elaborates two can provide a reproducible network benefiting the structural relationship between structural hole values. Subsequently, Nahapiet and Ghoshal divide entrepreneurial social capital into three dimensions: structural embedding, relational embedding and cognitive embedding social capital; they advocate that entrepreneurial knowledge creation, access and dissemination are embedded in the entrepreneurial social network. At home, the concept of "social capital” research relatively early in the view of social capital is a kind of relation network, social network is one of the most important human relations, and is an effective means of resource allocation.

As a branch of social capital theory, entrepreneurial social capital theory attracts more and more attention of scholars home and abroad. Foreign related theory is one of the few, foreign literature, only a few have direct mentions of entrepreneurial social capital concept, and the scholar thinks that entrepreneurial social capital opens up a new way, establishes the new entrepreneurial and solves the associated social problems [3]. Most of the literature use more entrepreneurial social network instead of direct entrepreneurial social capital concept. They think that entrepreneurial social network is composed of some special types of social relations which are connected by a series of contacts [4], the different aspects of network is composed of different types of relations. Entrepreneurial social capital embedded in the local culture and tradition [5] is a variety of institutions, networks, business partners of cooperation between products [6] and entrepreneurial support network [7], its basic starting point is the resources and benefits. Many domestic scholars use "en- 
trepreneurial social capital”. Main points are as follows: 1) The view of network. The view mainly holds that the social capital of entrepreneurs is closely related to entrepreneurial social network. 2) The view of resource. The view is defined whether entrepreneurs can obtain valuable resources and own the ability. 3) The view of integration. Entrepreneurial social capital should combine the entrepreneurial social network relations status and entrepreneur's ability of using resource together to define.

According to the different research objectives, scholars define the entrepreneurial social capital differently, generally its essence are establishment, operation and development of entrepreneurial relationship network of the internal and external. The ultimate goal is the mobilization of resources and capabilities through entrepreneurial social network [8]. Mixed view is integrated two views of the essence, which makes the concept more comprehensive, so this paper tends to comprehensively view definition.

\subsection{Coal Mine Entrepreneurial Social Capital}

There are many concepts of entrepreneurial social capitals, but coal entrepreneurial social capital concept in the literature is not much. According to the scholar of the entrepreneurial social capital in the comprehensive concept definition, this paper gives the coal mine enterprise entrepreneurial social capital concept. That is the coal mine enterprise's legal person's ability of obtaining the huge social relations cyber source quantity and capacity by themselves or enterprises. Its connotation includes two aspects: on the one hand, in colliery enterprise entrepreneur's occupation career, always get a certain relationship network and build the solid trust relationship from birth by lineal relatives by blood, the same village in, or through a rich educational experience of cultivating students, with the door, teacher-student relationship, or by changing the work department, and posting in the process of new colleagues. It seems that any entrepreneurs can accumulate these relationships, but what we called entrepreneurial social capital, not simply means a huge number of community cyber resources, but also focuses on the quality of social cyber source, and the capability of using valuable network resource for coal entrepreneurs. On the other hand, coal mining entrepreneur as a member of enterprise, play many roles. For example, as informer who contact different organization, as spokesman, as organizer who ordinate inside various departments. The various links among the various departments internal coal mine enterprise and external organizations in the coal mine production and operating activities, in essence, is the various staff relationship in these departments or organizations especially relationship between leaders [9].

\section{Coal Mine Entrepreneurial Social Capital Source and Its Mechanism of Action}

\subsection{Coal Mine Entrepreneurial Social Capital's Source}

Analyzing coal entrepreneurial social capital sources helps coal enterprise and entrepreneurs to broaden the accumulation social capital channel, in order to obtain more valuable social capital, further get more sustainable competitive advantage for coal mine enterprise. According to entrepreneur growing period the various sources are sorted as follows:

1) Coal entrepreneurial social capital base on family background.

American scholar Becker said: the family of human social life is the most basic one cell, though thousands of years, the social, economic and cultural environment has undergone tremendous changes, the family still retains the full system for maximum effect. While countryman neighborhood due to honor and interests, depend on each other and keep intimate relationship, easier to form a stable and lasting relationships.

2) Coal entrepreneurial social capital base on personal experience.

In this paper, personal experience includes two parts: on the one hand refers to coal entrepreneur's high quality and intimacy teachers or students relationship during education experience; On the other hand refers to the coal entrepreneur's business colleagues and boss who has ever cooperated, because of the common learning experience, understanding each other, and a certain amount of connect in the coal mines, this relationship has become the important source of entrepreneurial social capital.

3) Coal entrepreneurial social capital base on membership of coal mine enterprise.

Coal entrepreneurs play an irreplaceable role in the process of production, gradually it formed relationship network with inside the coal mine enterprise members, such as shareholders, employees, and with outside other enterprises, such as customers, suppliers, vendors, government, banks. The actual or potential resources in these two types of network constitute an integral part of entrepreneurial social capital.

\subsection{Mechanism Analysis of Coal Entrepreneurial Social Capital}

The important role of coal mine entrepreneurial social capital has been increasingly stood out in enterprise reform and safety production. The coal mine entrepreneurial social capital can not simply be imitated and is difficult to obtain, meanwhile it ensure the sustainable competition advantage of enterprise.

Main mechanism of entrepreneurial social capital in 
the coal mine enterprise point out:

Firstly, entrepreneurial social capital can improve organizational efficiency by raising the coal mine enterprise internal cohesion. The reduction of coal mine entrepreneurial social capital in safety production system implementation process may result in a series of contradiction and internal friction; In the coal mine enterprise, also exists informal interactive form, is one of the important factors of enterprise internal activities, which is not same the formal organizational structure. The skilled ability of management the entrepreneur internal cyber source can guarantee production and operating activities of continuity [10].

Secondly, coal mine entrepreneurial social capital can help to increase enterprise benefit by reducing the transaction cost. On one side, colliery entrepreneurial social network is built on the basis of trust and cooperation among network members. They have already cultivated good partnership which may reduce the information asymmetry and opportunistic behavior, corresponding to lower the transaction cost. On the other side, through various entrepreneurial the informal relationship network, colliery enterprise access to more market information, from the government, the industry, senior research institutions, which could increase market opportunities for coal enterprise and reduce the cost of time.

Thirdly, it's critical to enhance capacity access to scarcity resources for coal mine enterprise increasing more output. For coal mine enterprise, resources always appear to be lack, at the same time, can not meet the needs of their own development. However, the rich social capital of entrepreneurs, following useful social resource, can provide more choices to get the scarcity of resources and break the limited state, at last timely obtain needed resources. For example, priority to adopt of a new coal mining technology; and priority to understand the national energy development strategy and the adjustment of industrial structure policy and priorities for policy support.

\section{The Application Fields of Coal Mine Entrepreneurial Social Capital}

Researching on coal mine entrepreneurial social capital has just started, so this article will analyze its possible application areas and point out the possible development direction.

\subsection{Coal Mine Entrepreneurial Social Capital and the Construction of Safety Culture}

With the coal mine malignant accidents increasing in recent years, safety production has drawn the whole industry and all over the national attention and has become a hot topic. Coal mine enterprise safety culture includes two aspects: on one side, is safety concept, safety attitude, security quality, security facilities, security system, security mechanism and security visual identification system or the sum of all which must be obeyed by the coal mine entrepreneurs and its operator and practitioners in production and business activities. On the other side, is the coal mine enterprise safety production and operation of new way of thinking and behavior patterns taken by all means and measures [11]. Combined the mechanism action of coal mine entrepreneurial social capital to coal mine enterprise safety culture, another path of construction safety culture will be explored. Depending on the coal entrepreneurs' strong interpersonal skills and own strong R \& D capability, they not only reach collective trust by internal staff building good relationship network, but keep on conveying the spirit of safety culture concept and continuous running action to the whole enterprise. This affects how to play better, still need further research.

\subsection{Coal Mine Entrepreneurial Social Capital and Firm Performance in the Coal Mine Enterprise}

In recent years, the enterprise performance is becoming a hot point, which is mainly measured by corporate profit margins or the market share. Coal mine entrepreneurial social capital positive effects on the performance: firstly, is that the entrepreneur's valuable social capital can help enterprise to reduce internal management costs and reduce business transaction costs; secondly, the coal mine entrepreneur can use their social capital to obtain more precious market information and scarce resources, even advance technology to create more value. However, the existing research points the entrepreneurial social capital also has the negative influence on the enterprise performance. For example, if coal mine enterprise management dependent more on entrepreneurs, it will easily lead to the short-term action of the entrepreneur. Once the entrepreneur leave, the management system is likely to return to the origin and affect efficiency of enterprise [12]. Therefore, in-depth studying mechanism of coal mine entrepreneurial social capital influence on enterprise performance and discussing the coal mine social capital of entrepreneurial on how to more effectively promote the enterprise performance, is an important research direction in the future.

\subsection{Coal Mine Entrepreneurial Social Capital's Dynamics and Coal Enterprise Sustainable Development}

Coal is non-renewable resource, which make colliery enterprise take a path of sustainable development. Wanting to obtain the priority of master new mining technol- 
ogy, drilling technology, and safety production technology require coal entrepreneurs to use their social resources, for the coal mine enterprise cost savings, meanwhile create benefit. How to use coal entrepreneurial social capital to realize the sustainable development of the coal enterprise, there is of great research significance. In addition, the existing research is mainly based on the static perspective, however, the valuable coal entrepreneurial social capital is not fixed, when coal mine entrepreneurial social capital formation and development, coal mine enterprise can not only get funding and policy support from the government, financial institutions, but also obtain the technical cooperation and more important new knowledge from the university, scientific research institutions by the extensive cooperation with external main body. Therefore, based on the time series of dynamic perspective through a longitudinal case study [13], and further reveals the coal entrepreneurial social capital accumulation dynamic evolution law and effect on the coal mine enterprise sustainable development, while future research will be an important aspect.

\section{REFERENCES}

[1] P. Bourdieu and L. Wacquant, "Invitation to Reflexive Sociology,” University of Chicago Press, Chicago, 1992.

[2] Coleman, "Foundations of Social Theory," Social Science Literature Press, Beijing, 1990, p. 333.

[3] H. Westlund and R. Bolton, "Local Social Capital and Entrepreneurship," Small Business Economics, Vol. 21, No. 2, 2003, pp. 77-123. doi:10.1023/A:1025024009072

[4] E. Laumann, L. Galskeiwicz and P. V. Mardsen, "Community Structure of Interorganizational Linkage,” Annual
Review of Sociology, Vol. 4, No. 1, pp. 455-484. doi:10.1146/annurev.so.04.080178.002323

[5] B. Batjargal and M. Liu, "Entrepreneurs' Access to Private Equity in China: The Role of Social Capital," Organization Science, Vol. 15, No. 2, 2004, pp. 159-172.

[6] L. J. Spence, R. Schmidpeter and A. Habisch, “Assessing Social Capital: Small and Medium Sized Entrepreneurials in Germany and the UK," Journal of Business Ethics, Vol. 47, No. 1, 2003, pp. 17-33. doi:10.1023/A:1026284727037

[7] O. Jones and K. Boles, "Building Entrepreneurial Support Networks Social Capital and the NES Programme,” Management Research, Vol. 25, No. 8-10, 2002, pp. 87-91.

[8] S. Y. Yang and Z. Zhu, "Review and Expectation of Social Capital Research,” Journal of Chongqing Technology and Business University (Social Sciences Edition), Vol. 2, 2009, pp. 65-67.

[9] X. H. Zhou, "On the Social Capital of Entrepreneurial and Organizational Effectiveness,” Journal of Anhui Normal University (Human \& Science), No. 1, 2002, pp. 1-3.

[10] P. P. Yang, D. F. Wang and T. L. Wang, "Entrepreneurial Social Capital and Its Relationship with Firm Performance-Literature Survey and Theoretical Framework," Modern Economic Science, Vol. 4, 2005, pp. 87-88.

[11] Z. H. Ren, "People-Oriented Construction of Coal Mine Entrepreneurial Safety Culture System," Shanxi Energy and Conservation, Vol. 4, 2010, p. 23.

[12] W. H. Wu and H. Wang, "The High-Tech Entrepreneurial Social Capital Affects the Performance of the Approach and Mechanism," Science and Technology Progress and Policy, Vol. 15, 2009, pp. 158-160.

[13] F. P. Ma, “Top Managers' Social Capital Influence on Entrepreneurial Performance Research,” Coal Economic Research, Vol. 11, 2010, p. 41. 